\title{
10 The Political Economy of Reform: Labour after Soeharto
}

\author{
CHRIS MANNING
}

The dramatic changes of 1998 in the political and economic environment brought to the fore tensions between economic and social policy that had simmered near the surface for three decades under Soeharto. These strains were felt acutely especially in areas where the interests of large, disadvantaged, social groups were perceived to have been sacrificed in the quest for faster economic growth and crony business expansion. In several key areas where economic and social policy intersect, such as labour, agricultural policy and land rights, since Soeharto fell there has been a significant shift in favour of social groups disadvantaged during the New Order. This chapter focuses on one such group, wage workers in the formal sector.

Labour policy is one domain in which the rights of a significant social group, wage workers, were neglected in the interests of greater political and economic stability during the Soeharto period (see Hadiz 1997). It is no surprise therefore that labour reform was high on the agenda of the early reformasi governments led by Habibie and Abdurrahman Wahid in 1999-2001, and continued to receive close attention as the new democratic political format was consolidated under Megawati and Susilo Bambang Yudhoyono from 2001-07.

However, suppression of organised labour was not the only legacy of the Soeharto regime. It had also adopted a classic East Asian model of encouraging increases in exports and jobs in labour intensive industries, which contributed to poverty decline. ${ }^{1}$ The spate of new jobs raised expectations for improvements in living standards among poorer sections of the community. At the same time, as manufacturing exports took off, the Soeharto government in its later years had sought to provide greater protection for wage workers, through minimum wages

\footnotetext{
1 The four 'Tiger' economies of South Korea, Taiwan, Singapore and Hong Kong all achieved significantly improved living standards partly through jobs created in export-oriented industries in the first 20 years of rapid economic growth (World Bank 1993).
} 
and other labour legislation, partly in response to domestic and international criticism of Indonesia's labour rights record. The Soeharto legacy in labour policy is more complex and multi-faceted than is commonly recognised.

Dealing with the potential conflict between political transformation and greater freedoms on the one hand, and economic performance which provides jobs for the poor, is not a uniquely Indonesian dilemma (Haggard 2000). It is not surprising, therefore, that the post-Soeharto governments have faced difficulties in reconciling the labour reform agenda with broader economic development goals. Similar problems have been faced by other countries which have made the transition from autocratic to more democratic political systems, especially in Latin America during the late 1980s and 1990s (Cox-Edwards 1997).

However, it is argued in this chapter that the contradictions between social and economic policy have been quite stark in the case of Indonesia. They are particularly manifest in the policies of Indonesia's fourth president in the postSoeharto era, Susilo Bambang Yudhoyono, elected for a first five-year term in 2004. Yudhoyono set ambitious targets for reducing unemployment as one of the main goals of his government. At the time of writing, six years into the term of the government's term in office, it seemed less likely to achieve employment goals than successive governments under the New Order.

Part of the dilemma for the government relates to how governments weigh up policies designed to promote the welfare of formal sector wage workers as against those seeking to support the interests of labour in general. These wage workers not only account for a minority of all employed persons in Indonesia (as in other developing countries), but can have quite different interests to those in small enterprises and the informal sector. Conflicts of interest arise from the impact that greater government-mandated protection of formal sector workers ('insiders'), as opposed to more decentralised collective bargaining, has on labour costs and job opportunities for 'outsiders', those mainly in the informal sector. In the East Asian context, a major avenue for improvement in living standards among outsiders in the early stages of development had been through providing them with access to formal sector jobs, mainly in internationally competitive, labour-intensive industries, such as textiles, clothing, footwear, furniture and electronics (Galenson 1992; Fields 1994). ${ }^{2}$ Government-mandated protections of conditions for insiders already located in the formal sector can be a barrier to the entry of these outsiders.

The views of economists commonly diverge from those of many other social scientists on the social costs of different approaches to labour policy in Indonesia.

2 Note that these improvements are relative to less favourable jobs in many informal enterprises. By First World standards, of course, wages in the textile, clothing and footwear industries, are still very low, and have been a subject of widespread criticism by labour activists. 
Other social scientists and lawyers, focusing on the denial of labour freedoms in the New Order period, have generally welcomed changes in the legislative framework since the downfall of Soeharto (eg Lindsay and Masduki 2002; Caraway 2006). They draw attention to more independent labour unions, an improved industrial relations climate and greater compliance with labour laws in the post-Soeharto era. In contrast, many economists have focused on a different set of variables, in particular the slow rate of investment and employment growth in the formal sector. They have drawn attention to the potentially harmful mix (from the point of view of job creation) of a more active union movement and extensive labour protection mandated by the government authorities. In the Indonesian context, it has been suggested that this has contributed to steeply rising labour costs and employment arrangements which are not conducive to job creation (World Bank 2005).

I take up some of these issues in the chapter. The second section of the chapter delves briefly into the relationship between political and economic reform, both in general and with specific reference to Indonesia. This sets the scene for a more detailed discussion of the political economy of labour policy in the third section. Three episodes are discussed briefly: the controversy over legislation on levels of severance pay and redundancy arrangements, the dramatic increases in minimum wages in 2000-02, and the half-baked and ultimately unsuccessful attempts to revise clauses in the 2003 Manpower Protection Act under Yudhoyono in 2005-06. In the fourth section, the discussion turns to labour outcomes, focusing on employment and drawing contrasts between the Soeharto and post-Soeharto years.

\section{Political change and economic policy in Indonesia}

Autocratic systems of government, like that of Soeharto, have a mixed economic record (Williamson 1994). ${ }^{3}$ Nevertheless, autocratic governments have the means to implement far-reaching economic reforms, because they exert control over the political system - including electoral processes (if any), cabinet appointments, and the legislature - and dominate interest groups, the media and the bureaucracy (Haggard 2000). International experience suggests, however, that this is by no means a sufficient condition for success. Necessary characteristics include leaders with a long-time horizon and ability to select a team of economic

3 Economic reform is defined loosely to include policy changes which promote economic growth through more efficient allocation of resources, and increased savings and investment. Key elements of the policy mix include relatively stable and predictable macro-economic conditions, a more open economy and government policies which promote domestic and foreign investment in competitive industries. 
advisers, often in key economics cabinet positions, with a strong allegiance to the leadership, such as in the cases of Chile and Singapore (Pinera 1994). A clear strategy is needed on the sequencing of reforms to promote sustained economic growth. Reform-oriented governments also need some luck. Exogenous domestic or international shocks to the economy can derail the reform process, although one measure of successful autocratic leaders is the capacity to devise strategies to cope with crisis.

An abrupt transition to a democratic regime, as occurred in Indonesia in 199899 has the potential to disturb many of the conditions which underpin economic expansion under a pro-growth autocratic government. This is especially true where the changes required to sustain growth threaten the livelihoods and economic standing of interest groups, or significant sections of the wider community. The government, especially if it is part of a coalition, loses many of the levers that ensure the successful implementation of economic reforms. It is no longer able to control electoral processes, or to ignore interest groups or censor what is printed in the media, given the necessity of preserving public support for electoral purposes. Unless it is supported by a strong professional bureaucracy, new democratic governments can find it difficult to stick to a consistent reform program, especially if key economic portfolios are held by coalition partners with a different policy priorities. In presidential systems, weak control over the legislature has the potential to slow or even halt economic reform programs.

\section{Economic policies under Soeharto}

Especially in the first two decades, Indonesia under Soeharto had many of the features of an autocratic government committed to economic progress (Bresnan 1994; Hill 2000). The close working relationship between the president and the closely knit group of technocrats who controlled economic portfolios was a key feature of the regime. It not only enabled the passage of economic reforms which stabilised the economy, and promoted agricultural development, population control, trade expansion and foreign investment, but also helped Indonesia deal with periodic economic crises, especially in the early years of the regime (Hoffman et al 2007). The widely documented control over the electoral process, political parties, the legislature, the media and other potential opposition groups (including organised labour), enabled the government to press forward with its sometimes unpopular economic agenda without significant challenge. ${ }^{4}$

4 The effectiveness of the autocratic model for economic advancement waned after the break up of the cohesive technocrat team from the University of Indonesia; serious fault lines emerged within the cabinet and in the bureaucracy in the 1990s (especially the 'technolog' challenge to a more open, competitive economic 
Particularly relevant for our later discussion of labour policies, it is worth noting that Soeharto was no Pinochet when it came to explicit support for market-oriented economic policies, and nor were his 'Berkeley mafia' of UStrained technocrats as doctrinaire as the Chicago boys who managed the Chilean reforms (Pinera 1994). While the government initiated a raft of reforms (especially removing obstacles to trade and restrictions to foreign investment) that underpinned the export boom which occurred in the last decade of the regime, neither Soeharto nor his technocrats demonstrated a strong public commitment to a more open and competitive economy. ${ }^{5}$ The reform package was sold to the public as 'deregulation' rather than the conventional program of economic liberalisation that it in fact represented. Soeharto himself was no supporter of liberal economics. He frequently stated his preference for stateimposed 'co-operative' forms of ownership and distribution on the grounds they were the 'appropriate form of enterprise' for Indonesians (Soeharto 1989:233).

Similarly, as we shall see, reform of quite extensive labour protection, which constrained labour market flexibility in an increasingly competitive international economic environment, was never part of the government reform agenda under Soeharto, as it was in Chile under Pinochet (Edwards 1997). To the contrary, protective legislation was even extended during the later Soeharto years, in response to criticism of the regime's poor record on labour rights.

Both the preference for co-operatives and protective government labour regulations were a reflection of the strong paternalistic streak and ambivalence with regard to market solutions that marked Soeharto's approach to public policy. The same mindset is reflected in policies adopted by subsequent, postNew Order governments, especially that led by Susilo Bambang Yudhoyono.

\section{The politics of economic policy after Soeharto}

The institutional environment changed dramatically with breathtaking pace of political reform after the fall of Soeharto: the first free elections in 1999, 'big bang' decentralisation in 2001, constitutional reform in 2002, the first direct presidential elections in 2004 and elections for district and provincial governments over subsequent years.

policy; see Azis, 1994). Added to this was increasing alarm at the extent of economic favours granted to members of the first family, which began to undermine public support for the entire reform agenda initiated in the 1980s.

5 Soesastro, 1989, refers to the strategy of 'low politics' - reform almost by stealth than through direct confrontation with potential opposition groups - adopted by the technocrat reformers, which helps explain the relatively trouble-free adoption of market-oriented policies in the 1980s. This was possible in an environment where reform packages were not vetted publicly in the media, or comprehensively in the political arena, in constrast to the post-Soeharto era. 
After the initial three years of frenetic political change and sometimes chaotic economic policy making under B. J. Habibie and Abdurrahman Wahid, economic policy began to stabilise in the Megawati and then Yudhoyono presidencies. Several key patterns emerged. First, the power of the presidency and executive was weakened, and that of legislature strengthened. ${ }^{6}$ Economic cabinet ministers now were obliged to negotiate most major regulatory changes in the parliament. Major pieces of legislation such as revisions to the tax and investment laws all took at least twelve months and often much longer to gain parliamentary approval.

Second, ministers appointed in successive coalition governments no longer spoke with a single voice, nor did their ministries pursue a consistent line on economic policy, in contrast to cabinet ministers during much of the Soeharto era. Cabinets now consisted of broadly based multi-party 'rainbow coalitions' (see Aspinall in this volume). Different policy agendas emerged, for example between the Finance and Trade and Industry ministers over trade policy under Megawati, and between the ministers of Agriculture and Industry, on the one hand, and ministers in the key economic portfolios-Finance, Trade and the coordinating minister of Economic Affairs - on protection for industry policy (Awiscahyono and Hill 2004; Basri and Patunru 2006).

Third, interest groups, including business and labour unions, now had much more access to decision makers in the parliament, and the bureaucracy, as well as cabinet ministers who were no longer protected by a powerful president. In addition, there was now constant public scrutiny of government performance from civil society groups and the media. Later we shall see that that freedom of the press, in particular, has been important in putting pressure on government in the area of labour policy.

Finally, decentralisation meant that the central government no longer controlled some of the key levers of economic policy. Some areas of labour policy, such as the setting of minimum wages, have been decentralised, even though most laws are still the prerogative of the central government. ${ }^{7}$

Two other features of the policy-making environment are also relevant for labour policy in the reformasi era. Firstly, the media, many parliamentiarians and some cabinet ministers adopted a more nationalistic stance regarding foreign investment in certain sectors (such as mining) and international financial organisations (IFIs), such as the IMF and World Bank. The economic crisis had

6 The constitutional reforms of 2002 restored some authority to the president, even though she/he had much less absolute authority than during the New Order period, Ellis, 2007.

7 Indonesia is unlike some countries (such as India) where state governments can amend national labour laws for application within their own jurisdictions. 
dented Indonesian policymaker confidence in IFIs, not least for their strong advocacy of market solutions when Indonesia was on its knees during the financial crisis (Johnson 1998; Robison and Hadiz 2004:148-49).

Second, much resentment about about corruption, cronyism and human rights abuses had built up under Soeharto and now meant that less credit was to be accorded in the public discourse and political arena for the achievements of the Soeharto government. Besides the well-known economic 'miracle', these accomplishments were in areas such as employment growth and poverty alleviation, which were much less in the political spotlight after the crisis than issues such as repression of collective rights. Galvanising public support for 'neoliberal' economic reforms in areas such as trade reform, privatisation, or labour, was likely to prove a difficult task for the new post-New Order governments, precisely because of a widespread, popular belief that the Soeharto regime's economic policies had not benefited the poor significantly, if at all.

We now turn to labour policy in the new political environment.

\section{Labour policy in the post-Soeharto era}

Labour is one area where there were major changes in the institutional environment following the fall of the Soeharto regime. Most important was government recognition of the right to join trade unions and bargain collectively through ratification of ILO conventions and the Trade Union Law, No 21/2000, one of the first major laws passed after the fall of Soeharto just two years earlier. Multiple union structures were permitted in the form of national federations and larger confederations, after some 25 years when one government sanctioned union (Serikat Pekerja Seluruh Indonesia, SPSI or the All Indonesia Trade Union) was the only trade union organisation recognised by the government. ${ }^{8}$ Five years after the crisis, the total number of union members was estimated at close to 10 million, and may have increased somewhat since then (Quinn 2003:26). Although this number is almost certainly an overestimate, ${ }^{9}$ union activism was certainly on the increase in the post-crisis period. Workers were distributed over 60 union federations, and three major confederations that accounted for around over 80 per cent of all union membership. For economic

\footnotetext{
8 In response to heavy national and international pressure, independent company unions were permitted by the Soeharto regime in the 1990s. Alternative union bodies with multiple branches, most notably the Indonesia Prosperity Labour Union (Serikat Buruh Sejahtera Indonesia, SBSI), were also formed, despite official opposition, see Hadiz, 1997.

9 The true number of dues paying members is probably closer to 3-5 million with a union density of perhaps around 5-10 per cent among wage employees.
} 
and social analysis, the most important implication from this expansion has been stronger pressures from trade unions for compliance with basic labour laws and standards, compared with the New Order period. ${ }^{10}$

Whereas under Soeharto, security officials, technocrats, politicians and businesspeople were appointed as Ministers of Manpower, several former trade unionists were appointed as Ministers of Manpower in post-Soeharto governments. ${ }^{11}$ These appointments were symptomatic of a major shift in government policy towards greater support of labour rights and standards. Improved standards were promoted by the government through law No 13/2003 drafted by the Ministry of Manpower, and passed after long negotiations between the major union confederations and the employers organisation (Asosiasi Pengusaha Indonesia, APINDO) and presentations through 2001-02 by major stakeholders to the relevant parliamentary committee (Komisi VII). This law covers a wide range of labour protection issues, bringing together previous legislation scattered in a range of Ministerial and Presidential Decrees and government laws, as well as setting new standards in areas such as protection of female workers and procedures and compensation for lay offs and dismissals. ${ }^{12}$

The significance of these changes for the discussion in this chapter relates to the implications of a freer labour movement and an extensive set of regulations for adjustment of employment and wages to economic circumstances. Under Soeharto, regulations were extensive but compliance was low (Manning 1998). After reformasi, given greater compliance and more extensive regulations, one might reasonably conclude that Indonesia has one of the most regulated labour markets in the developing world, at least for larger firms in the formal sector. Developments after the fall of Soeharto stand in contrast to international trends in the directions of greater individual and collective bargaining in setting labour standards, especially in Latin America (IADB 2004).

The viewpoint that organised labour has gained through a combination of the new laws and greater compliance enforced by freer unions is a contested one. Caraway (2004) has argued that protective legislation inherited from Soeharto and enshrined in a single law in 2003 has provided a protective environment for labour employed in the modern sector. This applies especially to workers

10 See for example Suryahadi et al, 2003, on minimum wages which suggests higher levels of compliance with regulations in 2000 compared with before the crisis.

11 The two ex-union leaders who became Ministers of Manpower were Bomer Pasaribu, former Chairman of SPSI and an active member of Golkar, and Jacob Nuwa Wea, also an SPSI unionist but a strong supporter of the PDI-P before the downfall of Soeharto. The former was minister in an early Abdurrahman Wahid cabinet (1999-2000), and the latter in the Megawati government 2001-04.

12 The law deals with basic protection issues (such as hours of work, overtime, and minimum wages), protection of vulnerable workers (children, females, and contract and migrant workers) and basic principles for collective bargaining and industrial relations, including sanctions for non-compliance. Many of the issues have been subsequently regulated in implementing legislation, see Manning and Roesad, 2007. 
represented by the now freer, smaller unions that are unable to match employers in collective bargaining. In contrast, others have argued the laws have facilitated wider use of flexible labour arrangements, especially the employment of contract workers under less favourable conditions compared with regular workers (Tjandra 2008; Tjandraningsih and Nugroho 2008).

While there is little disagreement about greater use of contract labour since the law came into effect, cause and effect are debatable. Tjandra (pp.1, 7) argues that the new laws allow for a 'high degree of flexibility' and in practice there are 'massive violations' of the law in regard to provisions requiring the appointment of contract workers to permanent positions after a given period of employment with the firm. Tjandraningsih and Nugroho (p.6) also focus on the greater flexibility in labour management practices since the labour law was passed in 2003, which they also attribute to the law: '... a direct effect of the legislation been the introduction of flexible industrial relations practices in the form of contract labour and third party labour recruitment practices on a very large scale.'

Besides holding the view that the law is less binding on employers than in the past, other explanations for this shift in labour practices include greater product market competition and introduction of new technology (eg, Tjandraningsih and Nugroho, 2008:5-6). The possibility that the attempt to limit the number of permanent employees in many firms, and flout the laws, is due to the tightening (not loosening) of labour regulation with regard to remuneration and dismissal is not countenanced. This is one of the main arguments implicit in this paper, although our focus is on the actors engaged in the process of reform, some of the political processes underpinning them, and the employment implications, rather than on an analysis of changing labour practices.

\section{Three Labour policy episodes}

Three episodes in labour reform in the post-crisis period illustrate some of the key features of the changed political environment and its significance for public policy in the post-Soeharto era: revisions to legislation concerning severance pay for laid off workers; large minimum wage increases in the period 2000-02 and attempts to revise the labour laws under the Yudhoyono administration in 2005-06.

In each of the above cases, the Ministry of Manpower and ex-Ministers with a labour union background, played a central role in promoting new initiatives, all involved vigorous public debates and media coverage, and the involvement of interest groups, both employer organisations and labour unions. Two - the minimum wage increases and the revisions to severance pay-had regional dimensions. Each was ultimately resolved in favour of wage workers. 
All three areas of policy had been on the Soeharto government's political agenda in the 1990s. ${ }^{13}$ Minimum wages were raised quite significantly during the late Soeharto years when they were revised annually, for the first time in all provinces across the country. Severance pay rates were also increased by regulation in 1996, and a new labour law was drafted by the government in the last years of the Soeharto government. As in the post-Soeharto years, the main actor was the Ministry of Manpower, but on that earlier occasion change was initiated, perhaps surprisingly, by a minister who was also a prominent businessman: Abdul Latief, who had been appointed by Soeharto to the cabinet for the 1993-98 period. As noted above, the main labour initiatives were in part a response by the Soeharto government (probably with the strong support of the president) to increasing national and international criticism of its labour policies, including 'exploitation' of low-wage Indonesian labour in foreign dominated, export-oriented industries.

The cost of laying off workers. The first example relates to rising costs of laying off workers and illustrates the extent of influence on policy exerted by mass action in the post-Soeharto years. In 2000, changes to severance pay arrangements (Ministerial Decision No 150/2000) were introduced by the Minister of Manpower and former SPSI union leader and prominent Golkar politician, Bomer Pasaribu (see Manning 1998:172-98). Ministerial Decision 150 raised the rate of severance and long service pay and extended coverage to new groups of workers. In response to strong representations made by APINDO, which objected especially to the payment of severance to workers dismissed for criminal acts, the legislation was initially overturned by a Ministerial Decision No 78 of 2001. But heavy media criticism of the reversal of the decision in favour of business and major demonstrations by workers in several cities (including the threat of violence by demonstrators in Bandung) led to an almost immediate reinstatement of the original decision by the Minister of Manpower.

A compromise was reached two years later in the above-mentioned law, No 13/2003 on Manpower. Unions accepted revisions to clauses which denied severance and long service pay to workers laid off for criminal offences, or who quit voluntarily, in return for further increases in rates of severance. For business this was a somewhat pyrrhic victory: severance rates were now very high by international standards (Manning and Roesad 2007). ${ }^{14}$

The Jakarta minimum wage. The second episode of contentious labour policy involved unilateral action by regional interests supported by a pro-labour Minister. At the end of 2001, Soetiyoso, the Governor of Jakarta sought a rise

13 See Manning, 1998, Chapter 7 for a detailed discussion of labour reforms during the Soeharto era.

14 In most countries, severance pay and long service leave is mandated at 4-8 months pay for workers dismissed after 5-10 years service. In the Indonesian case, they amount to close to 2-3 times this amount: 15-20 months pay for similar durations of employment, Manning and Roesad, 2007. 
in minimum wages in the national capital for 2002 of just under 40 per cent in one year, which would have been one of the largest rises in workers' pay in Indonesian history. The increase was championed by Soetiyoso, in the year in which he was seeking re-election as Governor. The minimum wages were to apply only to the special region of Jakarta, but had important flow on effects for minimum wages in other provinces, especially neighbouring West Java.

In this case, the wage increase was challenged in the courts by the employers association APINDO, on the grounds that they were not based on the official guidelines for wage increases set out by the Ministry of Manpower, and would be harmful to its members. APINDO initially won the appeal in one Jakarta district court, but this ruling was subsequently overruled by another district court. In this case, this policy initiative was strongly defended by the Ministry of Manpower, under new Minister of Manpower, Jacob Nuwa Wea, a staunch Megawati supporter and former labour union activist in the Soeharto period. Jacob's appointment as Manpower Minister under Megawati was widely viewed as a move to try and shore up labour support for PDI-P leading up to the 2004 election. ${ }^{15}$

The controversy was widely reported in the Jakarta media, with most commentators supporting the increases. Most argued that Indonesia's wages were too low by international standards, although some reports included warnings from foreign chambers of commerce with regard to the potential impact of such major increases on labour costs and employment. ${ }^{16}$ As in the case of dismissals, the issue was resolved in favour of organised labour, despite the potential threat to employment, which has been considered historically a key area of policy concern for organised labour.

Revising the Labour law. Finally, the case of the labour law revisions illustrates, once again, how vulnerable government was to mass action on the part of labour unions, and it also demonstrates the latter's suspicions of governmentbusiness reform agendas. The Ministry of Manpower made recommendations, during discussions with unions and employers in February 2006, for significant revisions of some of the more controversial clauses of the manpower law No 13/2003, including the level of severance pay discussed above and restrictions on the employment of contract labour.

The proposal for revision of the law was extensive, surprisingly so, for a Ministry which had drafted and promoted the original legislation only three

15 See, for example, Mardjono, 2002, who argued the case for high wages increases on behalf of the Ministry in a paper presented to the parliamentary committee on labour and social policies.

16 See Ford, 2004 for a discussion of some of these issues. The Korean Chamber of Commerce argued strongly that large wage increases were raising labour costs too quickly (see Jakarta Post, 24 August 2002), For arguments in favour of the wage increases, see for example articles by Ballinger and Keady (Jakarta Post, 18 January 2002, p.5). 
years earlier (Manning and Roesad 2007). ${ }^{17}$ It appears that the main initiative had come from government agencies concerned about slow economic growth. Revisions of the labour legislation had been incorporated together with other proposed legislative changes (including the tax, customs and investment laws) in the Economics Coordinating Minister's plans to improve the investment climate (Coordinating Ministry for Economic Affairs, 2006). The World Bank in particular had provided strong public support of reforms in all these areas during 2005, including co-hosting a major international conference in cooperation with the Indonesian Chamber of Commerce (Kamar Dagang dan Industri, KADIN), and opened by the vice-president, Jusuf Kalla, in November of that year (World Bank 2005).

The proposed reforms met with stiff opposition. All the major union confederations rejected the proposed changes to the labour law out of hand, partly because they felt that they were not sufficiently engaged in drafting the original draft proposal. The government was faced with increasingly vocal opposition, culminating in major demonstrations in Jakarta and in several other cities in April and May in 2006, the largest of which was reported to involve close to 100,000 people (almost certainly an overestimate) in Jakarta on 1 May, followed by a subsequent smaller demonstration involving some destruction of public property outside the parliament building in Jakarta several days later. ${ }^{18}$

Although the shows of opposition were not extreme by international standards, President Yudhoyono announced quickly in May that proposed revisions to the labour law were to be withdrawn from the national economic reform package, only several months after they had begun to be debated in the public domain. He appointed a 'Five University' team of experts (including economists, lawyers and sociologists) to examine options for labour reform. The team later recommended several changes to regulations to help promote employment. ${ }^{19}$ Privately, however, senior government and KADIN officials conceded that any significant revisions to the labour law were almost certainly off the government reform agenda for the rest of the Yudhoyono's term of government.

These three cases of decision making over labour-policy issues demonstrate both breaks with political-economy processes under Soeharto, as well as

17 It covered all major areas which had been questioned by business groups, including severance pay rates, restrictions on the employment of contract workers and provisions with regard to minimum wages.

18 See Jakarta Post, 2 June 2006, 4 June 2006. Strikes in protest against the law led by the Confederation of the Indonesian Workers Union (Konfederasi Serikat Buruh Indonesia, KSPI) had begun in late March especially in the Bandung region and had become widespread in follow-up actions in early April 2006. See reports in Pikiran Rakyat, 24 June 2006 and Jakarta Post, 6 June 2006.

19 The committee was chaired by Professor Armida Alisjahbana of Padjadjaran University, Bandung. Its report was submitted to Boediono, the Economics Coordinating Minister in August 2006. It is noteworthy that all of the major union confederations declined to give submissions to the committee, which held a series of closed meetings with stakeholders from mid-May to July. However, some of the committee's recommendations were subsequently examined through union-employer discussions during 2007. 
elements of continuity. Politicians and bureaucrats were now more responsive to political pressure through interest group representation, mass action and the media, than in the Soeharto era. While several senior officials including ministers in key economics ministries, believed that labour regulations were hurting employment, very few were prepared to state this publicly or to take the lead in challenging the Ministry of Manpower's strong support for greater government mandate protection of workers. Senior officials within the employment division within the national planning agency (Badan Perencanaan Pembangunan Nasional, Bappenas), had made consistent public representations for less rigidity in employment and wage regulations over the period 2002-04. But they privately acknowledged that the political odds were stacked against reform, especially after the new Manpower Act was passed in 2003. This was despite some compelling empirical evidence which suggests that regulations were harming employment. ${ }^{20}$

Fear of union and wider community backlash against any reforms which appeared to be against the interests of labour (in this case represented mainly by wage workers in the modern sector), meant that reforms aimed at reducing hiring costs and rigidity in employment and wages were too sensitive a subject for political leaders. Like the term economic 'liberalisation', labour market 'flexibility' remains a hot potato in the Jakarta political lexicon, as it does among many labour union and NGO leaders internationally. It should be no surprise, therefore, that none of the major political parties publicly supported winding back restrictive clauses in the labour law, or sided with business in its attempts to modify severance pay and minimum wage regulations.

Also, unlike in the Soeharto period, among interest groups the unions were quite effective, and the employers federation much less successful, in lobbying for changes in public policy. While the government had given a public commitment to employers organisations to reform labour regulations, as part of a strategy to improve the investment climate, it was not able to deliver on its promise.

However, there were also important areas of continuity in policy. The unions were able to gain public support, precisely because of an expectation that the country should continue to rely heavily on government-imposed labour market regulations to set standards, rather than collective bargaining. Paternalism persisted as part and parcel of the labour regime inherited from Soeharto, underpinned by a common belief that far-reaching government regulation was necessary to protect workers from rapacious employers which was, perhaps ironically, another legacy of the Soeharto period.

20 The results of these studies were reported in a Bappenas 'White Paper' issued in 2003, see Indonesia. Bappenas, 2003. 


\section{Employment in the New Order and post-New Order periods}

This brings us to contrasts in the New Order and post-New Order periods in terms of employment. Employer interests were accorded higher priority in the New Order period, and the government pursued economic growth and employment objectives that extended beyond the interests of formal sector workers. Even though regulation was already extensive, and hence might have constrained investment decisions, employers could always find ways around the laws, either by buying the support of official labour union representatives, or by coercing workers who demanded better conditions of work that were in line with regulations (Hadiz 1997). De facto, the regulations did not matter nearly as much as in the reformasi period, and hence there was less conflict between regulation and job creation.

Three sets of data - trends in employment in manufacturing and the informal sector, and in unemployment rates - suggest Indonesia has struggled with jobs in the post-crisis period in precisely those areas where the more extensive labour protection laws and new industrial relations arrangements are important. Data on trends in each of these three areas are shown in Figures 10.1-10.3. ${ }^{21}$ They are quite disturbing from the perspective of job creation in the formal sector, which was the major engine for improvement in labour incomes - both in terms of jobs and higher wages - in the Soeharto period (Manning 1998).

Figure 10.1 shows employment growth by major sector of the economy in the six years before the crisis, and six years after relative economic stability was achieved around the year 2000. Two major contrasts are apparent. First, employment growth has been minuscule in the more recent period compared with the late Soeharto era in manufacturing and services, the two sectors which employ a high proportion of wage workers. ${ }^{22}$ The contrast was especially marked in manufacturing. ${ }^{23}$ From 2000, at a time when the total labour force was growing at around one and a half million per year, less than a miniscule ten thousand new jobs (not even one per cent of all new jobs created) had been added to the total manufacturing work force of some twelve million people. This contrasts with some 350-400 thousand new jobs created each year in manufacturing in the first half of the 1990s.

\footnotetext{
21 The figures are calculated based on data recorded in the annual (more recently bi-annual) National Labour Force Survey (SAKERNAS).

22 These two sectors have the highest proportion of jobs in wage employment. In services, wage workers are concentrated in the public sector, in personal services (especially maids) and education and health services.

23 The figure shows growth rates in employment of less than 0.1 per cent per annum in manufacturing, 0.2 per cent in services in from 2000-01, compared with 6 per cent and 4 per cent respectively, per annum, over the period 1990-96.
} 
Figure 10.1: Employment Growth, Indonesia 1990-1996, 2000-2006 (\% p.a.)

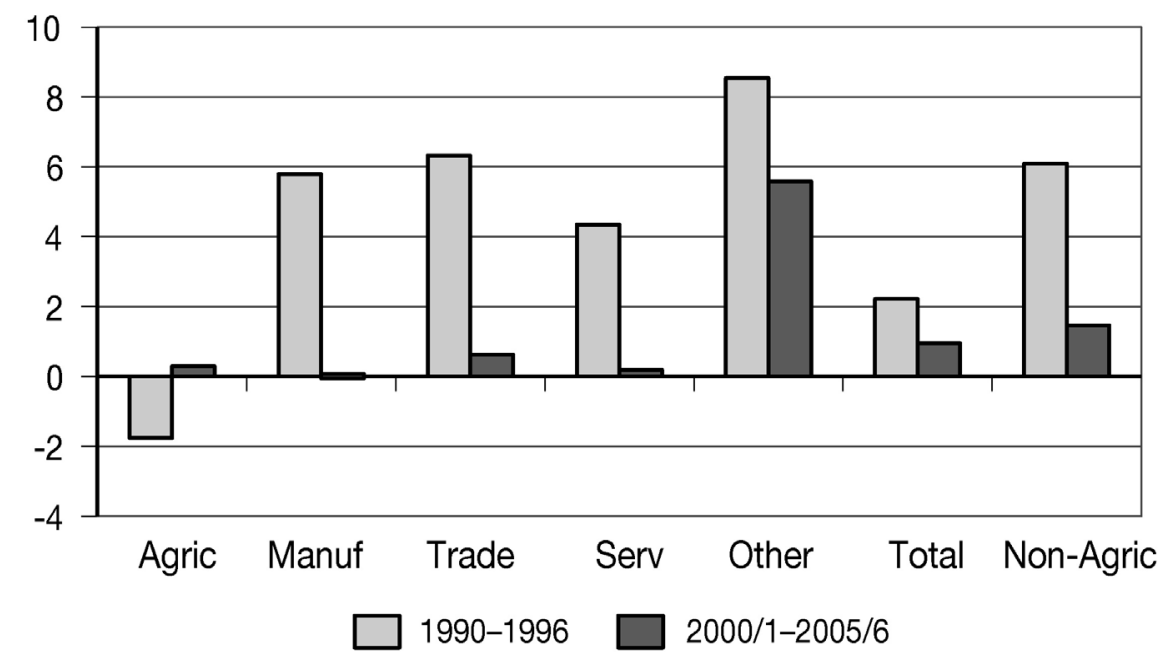

Note: Data for the second period are two year averages, owing to sharp annual fluctuations in several indicators.

Source: CBS (Central Board of Statistics), National Labour Force Surveys, Various Years.

Second, from the point of view of labour welfare, it has not just been the slow growth of jobs that is most alarming but the kinds of job opportunities that have dried up in recent times. Workers who had been attracted out of rural areas and into manufacturing and services in the pre-crisis period now sought new jobs back in low productivity agriculture, or in transport and construction (subsumed in the 'other' category shown in Figure 10.1). Output per worker in the agriculture sector still grew, but only at a little over half the pace recorded before the crisis. ${ }^{24}$ Indonesia, which had begun to follow the classic East Asian growth pattern of improved living standards through the shift of workers out of agriculture and into higher productivity activities in towns and cities, now experienced a reversal in this trend in the post-crisis period.

Employment rose briefly in response to increased competitiveness of exports and then declined quite steeply in the labour intensive sectors, textiles, clothing and footwear, or the so-called TCF industries after the crisis. ${ }^{25}$ Employment declined through to 2003, and was barely above levels achieved a decade earlier in these 'footloose' industries which tended to be vulnerable to both higher labour costs and more rigid employment arrangements. In contrast, new jobs in

24 From 1990-96, output per worker rose by just under 4.5 per cent per annum compared with under 3 per cent from 2000-01 (figures calculated from national accounts and labour force survey data).

25 Data on the industrial breakdown of employment come from the annual survey of large and medium manufacturing industries. 
larger firms pre-crisis were concentrated in these competitive export-oriented industries, which had absorbed many rural workers during the export boom from the mid-1980s. ${ }^{26}$

Associated with the above, another important response to the scarcity of new wage jobs has been a trend towards more informal sector work. ${ }^{27}$ This contrasts with the pre-crisis period when there was a marked shift away from agricultural and informal sector jobs in favour of more formal sector work (Figure 10.2).

Figure 10.2: Wage Jobs Outside Agriculture, and Agricultural and Other Non-Agricultural Jobs, Indonesia 1986-2004

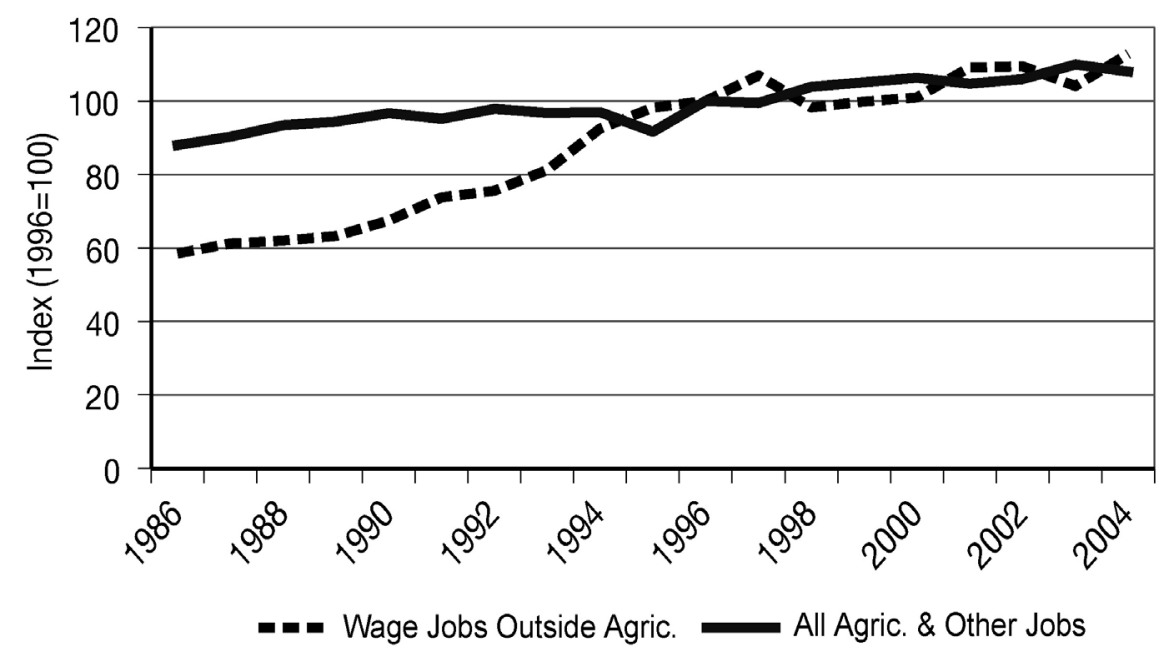

Note: Data for 1995 are interpolated.

Source: CBS, National Labour Force Surveys, Various Years.

Rising unemployment rates represent another piece of evidence, suggesting much more difficult employment circumstances after the crisis. ${ }^{28}$ Compared with more developed industrial countries, unemployment is not as important as an indicator of labour market conditions in less developed in countries like Indonesia, where unemployment benefits are not paid and few can afford to be unemployed. Nevertheless, these figures are worth mentioning because unemployment figures featured prominently in the debates on the government

26 From the mid-1980s employment in the TCF industries more than tripled over a decade from some 400 thousand to 1.3 million workers.

27 The formal sector is proxied crudely here by wage employment in non-agricultural sectors.

28 It is useful to bear in mind that unemployment rates are not always meaningful as an indicator of labour market conditions in countries like Indonesia where the informal sector is the main refuge for people who cannot get formal sector jobs, and there is no government unemployment compensation scheme. 
record in 2006-07 (bearing in mind that Yudhoyono made halving unemployment from just under 10 to 5 per cent one of his key promises during the election campaign in 2004).

After the crisis, unemployment did not recover as in most other East Asian countries. Rather the number of unemployed continued to rise steadily, and this helps explain why both formal sector jobs grew so slowly. Total unemployment reached double-digit figures by November 2005 for the first time in Indonesia's history (Figure 10.3). Just under half of all the unemployed were young, secondary educated people (mainly senior high graduates) aged 15-24, most of whom resided in urban areas, who might be expected to be queuing for formal sector jobs. ${ }^{29}$ Around one third of urban youth, with some secondary schooling, as well as a surprisingly large number in rural areas, were unemployed in 2004-06.

Figure 10.3: Unemployment Rates in Indonesia, 2001-2006

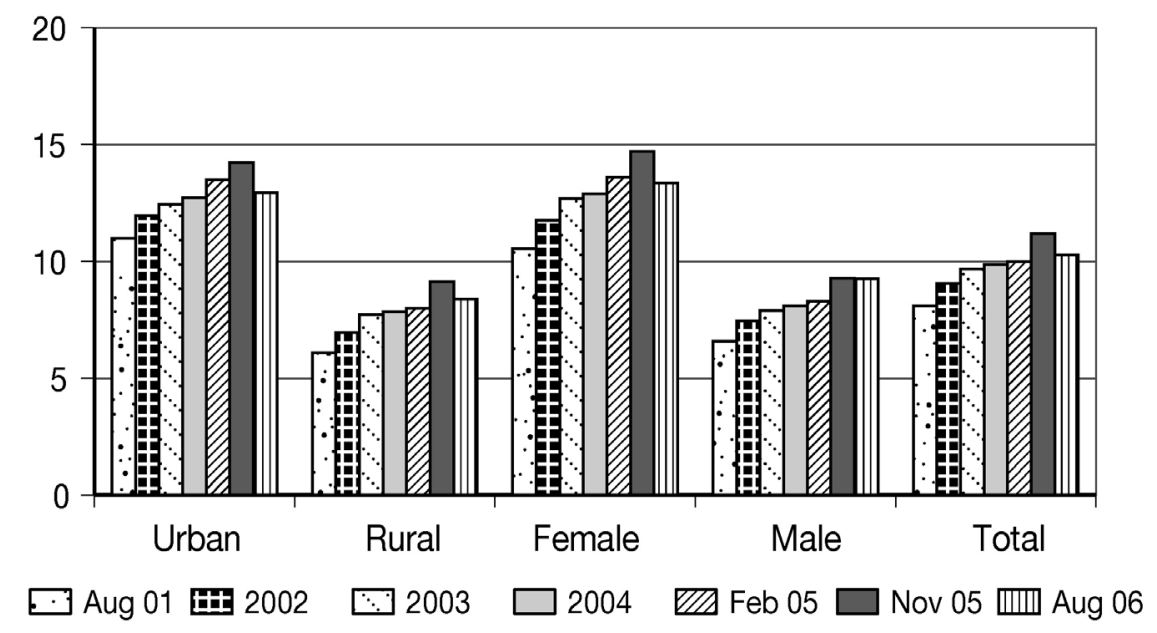

Source: CBS, National Labour Force Surveys, Various Years.

How much can we ascribe these trends in employment and unemployment to some of the labour regulations discussed in the previous section? Labour laws have certainly not been the dominant factor. A big part of Indonesia's employment problem since the crisis can simply be attributed to slower economic growth rates. Economic growth rates were half the rates recorded before the crisis, even after the economy had returned to relative stability by 2000 (Figure 10.4). In addition to labour regulations, a range of other factors have also been important. Uncertainties and the high cost of production in Indonesia relate partly to a less

29 These data are for 2004. The proportions of young educated among the unemployed have remained relatively stable since the crisis. 
unfavourable investment environment than before the crisis-especially long delays in the investment approval process, lack of transparency, illegal taxes and customs, and deterioration in infrastructure. ${ }^{30}$

Nevertheless, slower growth rates notwithstanding, the number of new jobs created for a given increase in production (output) was still very much smaller than before the crisis. A one percentage increase in output created less than half the number of jobs after the crisis, compared with the pre-crisis period. ${ }^{31}$ It is not only the rate of growth that has dented employment growth, but the growth that has taken place has not created enough jobs.

Figure 10.4: Growth Rates in Output (\% p.a., constant prices)

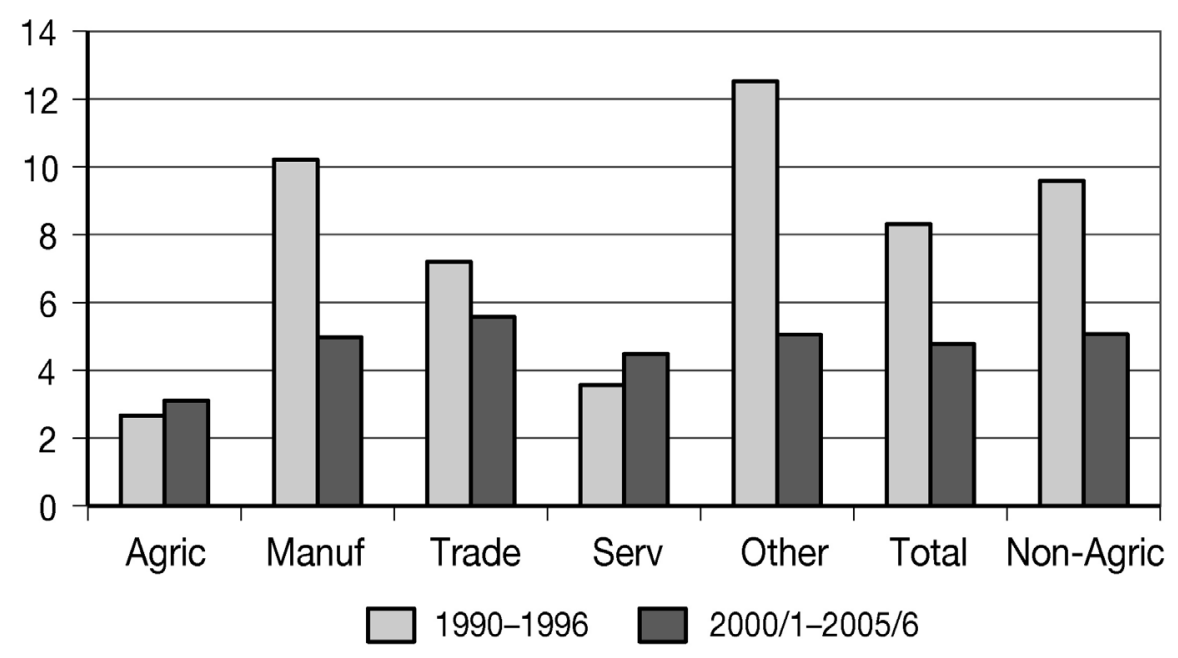

Source, CBS, National Accounts (reported in CIEC data base)

In the wider literature, this phenomenon is often referred to as 'jobless growth', and has been experienced by several developed, Latin American and other Asian countries such as Philippines, although not among the more rapidly growing Asian economies such as China and Vietnam (Asian Development Bank 2005). Technological change and import penetration from low cost producers such as China have been identified as the chief cause of jobless growth, although especially in Latin America, less flexible labour markets attributed to the regulatory environment (IADB 2004).

30 See the regular surveys economic developments in the Bulletin of Indonesian Economic Studies in 2005 and 2006 for detailed discussion of these developments.

31 In technical jargon, employment elasticities (which measure the percentage change in employment in relation to a one percentage change in output) halved in the non-agricultural sector over this period. 
Although still fragmentary, research does suggest that the new, restrictive labour regulations have contributed to the disappointing employment record, especially in labour intensive industries. Three factors have been important. First, with regard to wage regulation, minimum wages rose sharply and appear to have underpinned a similar increase in wages in manufacturing over the period 2000-05 (national average), despite depressed conditions of demand for labour. There is some evidence that these increases especially affected the employment of less educated, younger and female employees (Suryahadi et al 2003). Minimum wages were already close to median (average) wages for urban employees by 2000, suggesting that they were more 'binding' on employees than in the past. In other words, employers were more likely to observe regulations after the crisis, when unions were in a better position to ensure compliance, than during the Soeharto era.

Second, the high costs of severance - the lump sum payment paid when workers are laid off-bolstered by increased minimum wages, effectively imposed a substantial increase in fixed costs of employment. ${ }^{32}$ The increases compared with before the crisis were very high. Manning and Roesad (2007:66) report, for example, that severance costs almost tripled in three years in the period 2000-03. While some of these provisions were introduced before the crisis, few employers were considering laying off workers, in light of buoyant demand for labour at that time. The further increase in severance pay after the crisis occurred when many firms were already having to downsize, imposing additional costs. This provided the wrong signals to investors at precisely a time when severance pay rates and systems were being reformed in many other countries of the world, which were competing with Indonesia for investment (LP3E-UNPAD 2004). ${ }^{33}$

One reaction on the part of employers was to employ contract workers short-term or outsource some of their operations. For example, one survey of employment practices found that firms reportedly increased their use of fixed-term contract employment between 2001 and 2003, especially in manufacturing, as part of restructuring efforts (LP3E-UNPAD 2004: Figure 5.5). But subsequently provisions with regard to fixed-contract employment, and more importantly outsourcing of jobs, were also tightened in the new manpower law of $2003 .{ }^{34}$ In this respect, Indonesian regulations are more restrictive than in several other Asian countries (Bird 2005).

\footnotetext{
32 The increase in minimum wages are important for severance costs since rates of severance are based on the level of wages paid to workers at the time they are laid off (calculated on a monthly basis, depending on years of service).

33 There were no major extension of regulations in other East Asian countries which compete with Indonesia; in general severance pay rates were much lower in these countries than in Indonesia, see Bird, 2005.

34 The main provisions relate to a reduction in maximum duration of fixed term contracts and the limiting of outsourcing to activities outside the 'core' production activities of firms. See Manning and Roesad, 2007 for details.
} 
To sum up, despite public concern with the employment situation, the jobs situation worsened considerably after the crisis, much more than might have been expected if slower economic growth had been the only factor at play. The government responded by supporting workers in formal sector jobs, seemingly at the expense of employment opportunities for those without jobs, or who sought to move into formal sector jobs from the informal sector and agriculture. The policies backed 'insiders' who were a relatively easily identified group of regular wage workers with strong political support, at the expense of 'outsiders', most of whom were unorganised and worked in low and uncertain jobs in the informal sector and in agriculture. It is important to bear in mind that the newly created union bodies played an important role in the process, both through their active involvement in negotiations over the labour law, and in ensuring that regulations were complied with at the enterprise level. ${ }^{35}$

At the same time, it is important to note that labour unrest - which had been the main economic rationale for limiting union power in the Soeharto eraappears to have had a minor direct impact on employment. The incidence of strikes has remained low by historical and comparative standards (Quinn 2003). As far as actions in the labour sphere, extensive government controls seem to have been the main culprit.

\section{Conclusions}

This chapter has examined some political economy dimensions of economic and social policy making in Indonesia with special reference to labour. The focus has been on both continuities and changes in the design and implementation of policy in the post-Soeharto era, compared with that of the New Order. One legacy of the Soeharto era was a strong sense of injustice suffered by wage workers as a consequence of repressive labour policies. Another was a tendency towards state-directed paternalism in setting labour standards that were wideranging compared with most other East Asian countries. At the same time, the changed political circumstances under successive democratic governments after the crisis, led to greater divisions over policy within the government, and between different tiers of government with regard to labour. Greater regulation was encouraged by the periodic threat of mass action by labour unions and the increased influence of pro-labour interest groups (including a Ministry of Manpower that had been discredited as a defender of labour rights during the Soeharto years).

35 Higher levels of compliance with legislation, especially minimum wages, is another finding of the SMERU study on minimum wages in 2001, see Suryahadi et al, 2003. 
Labour legislation was extended in favour of formal sector workers, especially during the Megawati years of 2001-04, when the PDI-P had a major influence on labour policy, not least through its staunchly pro-labour Minister of Manpower, Jacob Nuwa Wea, who remained the leader of one of the major labour confederations throughout his term as minister. More generally, protection of wage employees has been viewed as politically expedient in the more democratic environment after Soeharto, even though modern sector workers make up a relatively small proportion of the working population. Such policies are especially attractive to governments, bearing in mind that the benefits of protection are easily identified and costs difficult to measure, especially in a country where most workers cannot afford to be unemployed and find jobs in the informal sector and in agriculture. ${ }^{36}$

I have also argued that employment outcomes differed significantly in both periods. While the Soeharto regime suppressed labour rights and extended tight controls over trade unions, it also presided over rapid expansion in formal sector employment and rising living standards for households who moved into better jobs in towns and cities. In contrast, the labour record in terms of job creation has been disappointing in the post-New Order era. This contrast in outcomes is rarely commentated on in the growing literature on labour in Indonesia, which focuses almost exclusively on trade unions, industrial regulations and labour rights. In sum, it has been suggested that post-Soeharto governments have traded off improved entry for outsiders into the formal labour market, for laws which protect wages and employment of existing workers or insiders, who were in a better position to exert influence on policy. But I also note that stricter laws are by no means the only factor contributing to the poor record on employment after the crisis.

From a standpoint of economic policy more generally, the analysis suggests that policies aimed at creating a more competitive economic environment is likely to be a much more difficult task for presidents and coalition governments in the post-Soeharto era. After the initial economic reforms 'forced' on Indonesia immediately after the crisis, the policies of early governments have been cautious with regard to market-oriented reform. As we have seen, they have also been strongly pro-organised labour. In light of a worsening employment situation, the Susilo Bambang Yudhoyono government initially sought to step back from several of the more extreme forms labour protection introduced during the Megawati years. But it faced opposition to revisions to the new labour law, and the president was not prepared to challenge the unions or jeopardise public opinion over the issue.

36 In industrial societies where most workers are wage earners, slow growth in employment mostly translates directly into higher rates of unemployment. Policies which discourage employment growth can have significant political costs. 
While the government under Yudhoyono remained broadly committed to an open, competitive economy, it was cautious on policies in areas where reforms might conflict with the apparent interests of vulnerable groups. For example, during 2005 and 2006 arguments for the removal of rice import restrictions, which stood to benefit the majority of poorer rice consumers, were rejected by the government on the grounds that farmers would suffer. Reforms involving complex distributive outcomes require strong support from the president, backing in the cabinet and from at least some of the major political parties. In this chapter, I have argued that the passage of such economic reforms may continue to be problematic in the more open political environment in the postSoeharto period. 